\title{
Studi Identifikasi Struktur Geologi Bawah Permukaan Untuk Mengetahui Sistem Sesar Berdasarkan Analisis First Horizontal Derivative (FHD), Second Vertical Derivative (SVD), Dan 2,5D Forward Modeling Di Daerah Manokwari Papua Barat
}

\author{
Ahmad Zaenudin, Shiska Yulistina* \\ Jurusan Teknik Geofisika, FT UNILA \\ Jl. Prof. Dr. Sumantri Brojonegoro No.1 Bandar Lampung 35145 \\ *e-mail:shiska.yulistina@yahoo.com
}

ABSTRAK

Secara garis besar Manokwari memiliki struktur geologi yaitu berupa daerah lipatan yang terdapat di kawasan dataran tinggi pegunungan. Di antara lipatan tersebut terdapat sesar naik dan sesar turun. Di kawasan pantai atau laut banyak dijumpai batuan terumbu karang dan koral. Penelitian gayaberat telah dilakukan di daerah Manokwari Papua Barat dengan tujuan untuk mengetahui struktur geologi bawah permukaan berdasarkan analisis FHD (First Horizontal Derrivative), SVD (Second Vertical Derrivative) dan pemodelan 2,5D Forward Modeling pada peta anomali residual daerah penelitian. Hasil penelitian menunjukkan bahwa daerah penelitian memiliki nilai Anomali Bouguer antara 4 mGal sampai $96 \mathrm{mGal}$ dengan anomali rendah pada bagian kiri daerah penelitian yang memanjang dengan arah relatif baratlaut-tenggara, anomali bernilai sedang berada pada bagian tengah daerah penelitian yang tersebar di daerah barat-timur, sementara untuk anomali tinggi tersebar pada bagian utara daerah penelitian. Hasil pemodelan bawah permukaan 2,5D serta analisis SVD dan FHD menunjukkan adanya sesar naik (Thrust Fault) pada penampang C-C', pada penampang B-B' terdapat adanya intrusi batuan Diorit Lembai dengan nilai densitas sebesar 2,75 gr/cc, sedangkan untuk penampang A-A' yang memotong sesar Sorong tidak ditemukan adanya sesar maupun intrusi batuan berdasarkan data observasi gayaberat daerah penelitian tersebut.

\begin{abstract}
In general, Manokwari has a geological structure that is in the form of a folding area found in the highlands of the mountains. Among the creases, there is a fault up and the fault down. In coastal or marine areas found many reefs and corals. The study of gravity was conducted in the Manokwari area of West Papua with the aim to know the subsurface geological structures based on FHD (First Horizontal Derivative), SVD (Second Vertical Derivative) and 2.5D Forward Modeling on the residual anomaly maps of the study area. The results showed that the research area has Bouguer Anomaly value ranged from $4 \mathrm{mGal}$ to $96 \mathrm{mGal}$ with the low anomaly at the left side of the research area lengthwise relatively in north-west to south-east direction, the middle-value anomaly spreads in the west-east area of research area, high anomaly scattered in the northern part of the research area. The results of the 2.5D subsurface modeling and the SVD and FHD analysis indicated the presence of a Thrust Fault on the C-C' cross-section, on the B-B' cross-section there is a Diorite Lembai intrusion with the density value is $2.75 \mathrm{gr} / \mathrm{cc}$, whereas the A-A' cross-section which intersects with Sorong fault were not found any fault or rock intrusion based on observed gravity data of the research area.
\end{abstract}

Keywords: Gravity, Bouguer Anomaly, Modeling 2.5D, SVD, FHD, Manokwari Area 


\section{PENDAHULUAN}

Tektonik Pulau Papua pada saat ini berada pada bagian tepi Utara Lempeng Indo-Australia, yang berkembang akibat adanya pertemuan antara Lempeng Australia yang bergerak ke Utara dengan Lempeng Pasifik yang bergerak ke Barat. Dua lempeng utama ini mempunyai sejarah evolusi yang diidentifikasi yang berkaitan erat dengan perkembangan sari proses magmatik dan pembentukan busur gunung api.

Secara garis besar Manokwari memiliki struktur geologi yaitu berupa daerah lipatan yang terdapat di kawasan dataran tinggi pegunungan. Di antara lipatan tersebut terdapat sesar naik (berupa bentukan daerah dataran tinggi dengan dominasi batuan sedimen batu kapur dan batuan pluton). Dan sesar turun (berupa bentukan lembahlembah dengan didominasi batuan endapan dengan sedimen lumpur dan organik dan alluvium). Pada kawasan-kawasan pantai atau laut banyak dijumpai batuan terumbu karang dan koral (Robinson dkk, 1990).

Bentukan struktur Sesar biasanya dapat diidentifikasi dengan menggunakan metode Gayaberat. Metode Gayaberat merupakan salah satu metode pasif geofisika, metode ini dilakukan berdasarkan pada anomali gayaberat yang muncul karena adanya variasi rapat massa batuan di bawah permukaan.

Metode Gayaberat merupakan metode yang sangat peka terhadap perubahan ke arah lateral. Oleh karena itu metode ini sering digunakan untuk memelajari cekungan sedimen, kontak intrusi, batuan dasar, struktur geologi, endapan sungai purba, lubang di dalam massa batuan dan lain-lain (Setiadi, dkk, 2018).

Dengan melakukan penelitian menggunakan metode gayaberat diharapkan dapat diketahui struktur bawah permukaan berdasarkan pemodelan FHD (First Horizontal Derivative), SVD (Second Vertical Derrivative). Forward modeling (2,5D). Hal-hal tersebut sangat penting sebagai data atau informasi awal mengenai sistem sesar yang terdapat pada daerah Manokwari, yang selanjutnya dapat ditindak lanjuti dengan survei yang mempunyai resolusi lebih tinggi.

\section{TINJAUAN PUSTAKA}

\subsection{Lokasi Penelitian}

Lokasi penelitian berada pada koordinat antara $0^{\circ} 20^{\prime}$ dan $1^{\circ} 00^{\prime} \mathrm{LS}$, dan antara $133^{\circ} 30^{\prime}$ dan $135^{\circ} 00^{`}$ BT sampai ke timur lembar ke selatan sampai $1^{\circ} 15^{\circ}$, yang terletak di ujung timur laut Kepala Burung, Irian Jaya sehingga meliputi pulau Numfoor. Daerah penelitian tersebut termasuk dalam daerah Manokwari yang secara administratif termasuk ke daerah Kabupaten Manokwari dengan Ibukotanya di Kota Manokwari Provinsi Papua Barat. Dan Pulau Numfoor yang termasuk ke dalam daerah Kabupaten Teluk Cenderawasih dengan ibukotanya Kota Biak. Daerah penelitian juga termasuk ke dalam Lembar Ransiki yang dibatasi oleh garis $1^{\circ}-2^{\circ}$ LS dan $133^{\circ}-134^{\circ} 30^{\circ} \mathrm{BT}$, yang mencakup pesisir timur Kepala Burung Irian Jaya, seperti dijelaskan oleh Gambar 1.

\subsection{Geologi Regional Daerah Penelitian}

Manokwari memiliki struktur geologi yaitu berupa daerah lipatan yang terdapat di kawasan dataran tinggi pegunungan. Di antara lipatan tersebut terdapat sesar naik (berupa bentukan daerah dataran tinggi dengan dominasi batuan sedimen batu kapur, batuan pluton). Dan sesar turun (berupa bentukan lembah-lembah dengan didominasi batuan endapan dengan sedimen lumpur dan organic dan alluvium).

Pada kawasan-kawasan pantai atau laut banyak dijumpai batuan terumbu karang dan koral. Informasi geologi Manokwari ini dapat diperoleh dari publikasi peta geologi lembar Manokwari dan Lembar Ransiki, Irian Jaya. skala 1 : 250.000 Puslitbang Geologi Bandung (Robinson dkk, 1990).

Manokwari meliputi tujuh satuan fisiografi yang terdiri dari Pegunungan 
tengah Kepala Burung, Dataran Arfak, Daerah perbukitan, Terumbu koral terangkat dan lintap gisik, Pematang batugamping, Dataran aluvium dan dataran pantai dan Bukit pencil batuan gamping.

\subsubsection{Stratigrafi}

Manokwari meliputi lima mendala geologi (Gambar 2). Mendala itu ialahBongkah (Blok) Kemum, Bongkah Tamrau,Bongkah Arfak, Sistem Sesar Sorong dan

Sesar Ransiki, dan Cekungan Manokwari. Ada bagian tertentu dari mendala tersebut yang tertutup endapan aluvium dan litoral Kuarter Dataran Arfak.

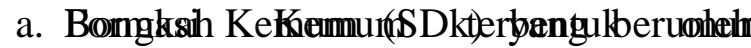

Silur hingga Devon berupa endapan malih derajat rendah sampai menengah. Yang terdiri dari kuarsit malih, batulanau malih, batusabak, rijang, sekis, sedikit batuan kalk-silikat, sekis hijau. Zona malihan biotit sampai andalusit.

Di tempat yang terpetakan, tubuh batuan digolongkan ke dalam Granodiorit Wariki (Trw), yang enam umur K-Ar nya berkisar dari 226-258 juta tahun, tetapi sebagian besar menunjukkan Trian. Batuan ini terdiri dari Granodiorit biotit, terdaunkan dan pejal biasanya tersesarkan. Batuan Bongkah Tamrau sebagai Formasi Tamrau (JKt) yang meluas dari MAR ke bagian Manokwari yang paling barat. Satuan ini terdiri dari batuan klastika silika yang berbutir halus dengan umur yang berkisar dari Jura Tengah hingga Kapur akhir. Dengan litologi yaitu serpih, batulanau, batusabak, dan batu pasir. Juga di barat terdapat bukit berbentuk sarang lebah yang berkembang pada teras atau sumbat gunungapi dan tersusun dari breksi andesit, andesit berangan (Tqbe).

b. Bongkah Arfak meliputi dua satuan. Yang lebih tua yaitu Batuan Gunungapi Arfak (Tema) dari busur kepulauan, dan umumnya terdiri dari batuan klastika gunungapi dan piroklastika, lava, breksi lava yang bersusunan basal sampai andesit dan batuan terobosan andesit, basal porfir, diorit, gabro dan jarang batugamping lumpuran.

c. Batugamping Maruni (Tmma) merupakan satuan atas dari bongkah Arfak. Satuan itu sebagian selaras dan sebagian tak-selaras menindih batuan gunungapi Arfak jauh di selatan di Ransiki. Satuan itu tersusun atas karbonat berbutir halus, yang mengandung foraminifera berumur Miosen Awal hingga Miosen Tengah.

d. Sistem Sesar Sorong dan Ransiki adalah ketidaksenambungan kerakbumi yang besar dan mewilayah, yang masingmasing mengikuti arah ke barat dan utara-baratlaut. Kedua struktur itu bersambung di Manokwari lewat endapan sesar yang terlengkungkan. Di Manokwari bagian barat sistem Sesar Sorong meliputi bancuh tak terpisahpisahkan (SFx). Batuannya terdiri dari klastika silikat gampingan dan tak gampingan yang tersesarkan dan setempat terambak kuat, dan batugamping mengandung kepingan tektonik berupa batuan malihan dan granit yang tak lazim. Dalam ruas sesar yang melengkung itu yang menghubungkan sistem sesar Sorong dengan sistem sesar Ransiki, Diorit Lembai (Tmle) muncul sebagai tubuh menganta yang umumnya terambak sangat kuat, terubah dan berurat. Umur terobosannya yang Miosen Tengah dipaksakan dengan sulit berdasarkan analisa isotop K-Ar.

e. Yang merupakan satuan dasar dan yang utama di cekungan Manokwari adalah Formasi Befoor (TQb) yang berumur Plio-Plistosen. Satuan itu menutupi batugamping Maruni dan di Ransiki dan bisa jadi di bawah permukaan Manokwari, Batuan gunungapi Arfak. Satuan itu meliputi batuan klastikasilikat tak gampingan dan gampingan berbutir halus hingga kasar setebal 1600 $\mathrm{m}$ yang mencerminkan pengendapan dalam lingkungan laut dangkal hingga delta dan estuarium. Satuan itu secara selaras dan tidak selaras tertindih oleh 
batugamping terumbu dan batuan klastika-silikat gampingan formasi Manokwari. Kedua satuan itu mempunyai kesamaan asal, tetapi sebagian rombakan dalam formasi Manokwari berasal dari Formasi Befoor. Formasi Manokwari merupakan satuan utama di P. Numfoor, tetapi tidaklah diketahui apakah Cekungan Manokwari meluas sampai sejauh itu ke arah timur dari daratan Irian Jaya.

\section{TEORI DASAR}

\subsection{Gaya Gravitasi}

Teori yang mendukung Ilmu gravitasi terapan adalah hukum Newton yang menyatakan bahwa gaya tarik menarik antara dua partikel bergantung dari jarak dan massa masing-masing partikel tersebut, yang dinyatakan sebagai berikut (Telford, dkk, 1990) :

$$
\vec{F}(r)=-G \frac{m_{1} m_{2}}{r^{2}} \vec{r}
$$

dimana, $F(r)$ adalah gaya tarik menarik (N), $m_{1}$ dan $m_{2}$ adalah massa benda 1 dan massa benda $2(\mathrm{~kg}), r$ adalah jarak antara dua buah benda $(\mathrm{m}), G$ adalah konstanta gravitasi universal $\left(6,67 \times 10^{-11} \mathrm{~m}^{3} \mathrm{~kg}^{-1} \mathrm{~s}^{-2}\right)$.

\subsection{First Horizontal Derivative (FHD)}

First Horizontal Derivative (FHD) atau Turunan Mendatar Pertama mempunyai nama lain yaitu Horizontal Gradient. Horizontal gradient dari anomali gayaberat yang disebabkan oleh suatu body cenderung untuk menunjukkan tepian dari body-nya tersebut (Blakely, 1996; Hartati, 2013; Zaenudin, dkk, 2013).

Jadi metode horizontal gradient dapat digunakan untuk menentukan lokasi batas kontak kontras densitas horizontal dari data gayaberat (Cordell, 1979 dalam Zaenudin dkk, 2013). Untuk menghitung nilai FHD dapat dilakukan dengan persamaan:

$$
F H D=\frac{g_{(i+1)}-g_{(i)}}{\Delta x}
$$

Dengan g merupakan nilai anomali (mgal), selisih antara jarak pada lintasan (m).

\subsection{Second Vertical Derivative (SVD)}

Second Vertical Derivative (SVD) dilakukan untuk memunculkan efek dangkal dari pengaruh regionalnya dan untuk menentukan batas-batas struktur yang ada di daerah penelitian, sehingga filter ini dapat menyelesaikan anomali residual yang tidak mampu dipisahkan dengan metode pemisahan regional-residual yang ada.

Dalam penentuan nilai SVD maka digunakan turunan kedua atau dilakukan dengan persamaan (Cordell, 1979 dalam Zaenudin, dkk, 2013):

$$
S V D=\frac{g_{(i+1)}-2 g_{(i)}+g_{(i+1)}}{\Delta x^{2}}
$$

Dalam penelitian ini, penulis menggunakan filter SVD hasil perhitungan Elkins (1951). Dalam penentuan patahan normal ataupun patahan naik, maka dapat dilihat pada harga mutlak nilai $\mathrm{SVD}_{\min }$ dan harga mutlak $\mathrm{SVD}_{\max }$. Dalam penentuannya dapat dilihat pada ketentuan berikut:

$|\mathrm{SVD}|_{\min }<|\mathrm{SVD}|_{\max }=$ Patahan Normal

$|\mathrm{SVD}|_{\min }>|\mathrm{SVD}|_{\max }=$ Patahan Naik

$|\mathrm{SVD}|_{\min }=|\mathrm{SVD}|_{\max }=$ Patahan Mendatar

Filter second Vertical Derivative (SVD) dengan operator Elkins filter 2-D ditunjukkan pada Tabel 1.

\subsection{Forward Modeling}

Forward modeling (pemodelan ke depan) adalah suatu metode interpretasi yang memerkirakan densitas bawah permukaan dengan membuat terlebih dahulu benda geologi bawah permukaan. Kalkulasi anomali dari model yang dibuat kemudian dibandingkan dengan anomali Bouguer yang telah diperoleh dari survei gayaberat. Prinsip umum pemodelan ini 
adalah meminimumkan selisih anomali pengamatan untuk mengurangi ambiguitas.

Pemodelan ke depan (Forward Modeling) merupakan proses perhitungan data dari hasil teori yang akan teramati di permukaan bumi jika parameter model diketahui. Pada saat melakukan interpretasi, dicari model yang menghasilkan respon yang cocok dan fit dengan data pengamatan atau data lapangan sehingga diharapkan kondisi model itu bisa mewakili atau mendekati keadaan sebenarnya (Talwani, dkk, 1969).

\section{METODOLOGI PENELITIAN}

\subsection{Tempat dan Waktu Penelitian}

Penelitian ini dilakukan di Pusat Survei Geologi (PSG), Bandung, Jawa Barat Pengolahan data di mulai pada bulan Februari sampai dengan Maret 2017

Adapun Alat dan bahan yang digunakan selama penelitian ini berlangsung yaitu data Gayaberat Kepulauan Manokwari, Peta Geologi Daerah Penelitian, Software Geosoft v.6.4., Software Numeri, Software Surfer v.12, Software Global Mapper v.12, Software Microsoft Word dan Excel 2007.

\subsection{Alur Penelitian}

1. Data gayaberat dalam penelitian ini adalah data gayaberat sekunder atau data gayaberat yang telah melalui berbagai koreksi-koreksi, sehingga diperoleh Anomali Bouguer Lengkap (ABL). Langkah pertama pada penelitian ini adalah membuat Peta Anomali Bouguer Lengkap (ABL).

2. Analisis spektral bertujuan untuk mengestimasi nilai kedalaman suatu anomali dan untuk mengetahui lebar jendela optimal yang akan digunakan untuk pemisahan anomali regional dan residual. Analisis spektral dilakukan dengan Transformasi Fourier dari lintasan yang telah ditentukan. Untuk analisis spektral penulis membuat 5 lintasan pada peta ABL, kelima lintasan diproses menggunankan perangkat lunak Geosoft 6.4.2, sehingga menghasilkan data jarak dan anomali Bouguer pada setiap lintasan.

3. Data jarak dan anomali Bouguer selanjutnya dilakukan proses FFT (Fast Fourier Tranform) dalam domain spasial $(\Delta x)$ tertentu.

4. Hasil dari proses FFT adalah nilai real dan imajiner dari setiap lintasan yang selanjutnya akan diproses dengan menggunakan perangkat lunak Ms.Excel untuk mendapatkan nilai amplitudo (A), In $A$, frekuensi dan nilai bilangan gelombang $k$. Nilai amplitudo (A) dihasilkan dengan cara menghitung akar kuadrat dari nilai real dan imajiner. Nilai In A dihasilkan dengan cara melogaritmakan nilai amplitude (A).

5. Setelah semua nilai diperoleh selanjutkan akan diplot grafik antara $\ln A$ (sumbu y) dan $k$ (sumbu $\mathrm{x}$ ). Dari grafik akan didapatkan dua gradien, gradien atau kemiringan garis dari grafik $\ln A$ terhadap $k$ adalah kedalaman bidang batas residual dan regional. Gradien yang bernilai besar mencerminkan bidang diskontinuitas dari anomali regional (dalam) dan gradien yang bernilai kecil adalah bidang diskontinuitas dari anomali residual. Perpotongan antara kedua gradien adalah bilangan gelombang $k_{c}$ (cutoff) yang merupakan dasar dalam menentukan lebar jendela. Nilai kedalaman rata-rata hasil regresi linear residual dan regional akan digunakan pada pemodelan struktur bawah permukaan.

6. Selanjutnya dilakukan pemisahan anomali regional dan residual dari anomali Bouguer dengan menggunakan filter moving average.

7. Tahapan selanjutnya melakukan analisis derivative untuk sebaran patahan pada daerah penelitian, analisis derivative juga dilakukan untuk membantu dalam pembuatan model 2,5D, analisis derivative yang digunakan pada penelitian ini adalah turunan pertama anomali Residual atau First Horizontal Derivative (FHD) dan turunan kedua 
anomali Residual atau Second Vertical Derivative (SVD)..

\section{HASIL DAN PEMBAHASAN}

\subsection{Anomali Bouguer}

Dalam penelititian ini penulis menggunakan data gayaberat sekunder, artinya data yang telah dilakukan berbagai koreksi, sehingga menjadi Anomali Bouguer Lengkap (ABL). Peta Anomali Bouguer di daerah penelitian menunjukkan rentang nilai anomali antara $4 \mathrm{mGal}$ sampai $96 \mathrm{mGal}$, hasil tersebut merupakan respon variasi rapat massa batuan yang ada pada daerah tersebut (Gambar 3).

\subsection{Analisis Spektral}

Pada peta Anomali Bouguer Lengkap daerah penelitian, penulis membuat lintasan sebanyak 5 lintasan, yaitu lintasan A-A' sampai dengan E-E'(Gambar 4).

\subsubsection{Lintasan A-A}

Hasil dari analisis spektral penampang lintasan A-A' menunjukkan kedalaman anomali pertama adalah 15,512 $\mathrm{km}$ yang diinterpretasikan sebagai kedalaman bidang kerak, dan kedalaman anomali kedua adalah $1,527 \mathrm{~km}$ yang diinterpretasikan sebagai batas antara batuan dasar (basement) dengan batuan sedimen. Perpotongan antara gradient pertama dan kedua adalah bilangan gelombang $k c$ (cutoff) yang memiliki nilai 0,270 (Gambar 5).

\subsubsection{Lintasan B-B'}

Hasil dari analisis spektral penampang lintasan 2 menunjukkan kedalaman anomali pertama adalah 10,675 $\mathrm{km}$ yang diinterpretasikan sebagai kedalaman bidang kerak, dan kedalaman anomali kedua adalah $1,544 \mathrm{~km}$ yang diinterpretasikan sebagai batas antara batuan dasar (basement) dengan batuan sedimen. Perpotongan antara gradient pertama dan kedua adalah bilangan gelombang $k c$ (cutoff) yang memiliki nilai 0,27 (Gambar 6).

\subsubsection{Lintasan C-C'}

Hasil dari analisis spektral penampang lintasan 3 menunjukkan kedalaman anomali pertama adalah 10,976 $\mathrm{km}$ yang diinterpretasikan sebagai kedalaman bidang kerak, dan kedalaman anomali kedua adalah 1,677 $\mathrm{km}$ yang diinterpretasikan sebagai batas antara batuan dasar (basement) dengan batuan sedimen. Perpotongan antara gradient pertama dan kedua adalah bilangan gelombang $k c$ (cutoff) yang memiliki nilai 0,279 (Gambar 7).

\subsubsection{Lintasan D-D'}

Hasil dari analisis spektral penampang lintasan 4 menunjukkan kedalaman anomali pertama adalah 4,174 $\mathrm{km}$ yang diinterpretasikan sebagai kedalaman bidang kerak, dan kedalaman anomali kedua adalah $1,471 \mathrm{~km}$ yang diinterpretasikan sebagai batas antara batuan dasar (basement) dengan batuan sedimen. Perpotongan antara gradient pertama dan kedua adalah bilangan gelombang $k c$ (cutoff) yang memiliki nilai 0,348 (Gambar 8).

\subsubsection{Lintasan E-E'}

Hasil dari analisis spektral penampang lintasan 5 menunjukkan kedalaman anomali pertama adalah 7,238 $\mathrm{km}$ yang diinterpretasikan sebagai kedalaman bidang kerak, dan kedalaman anomali kedua adalah $1,578 \mathrm{~km}$ yang diinterpretasikan sebagai batas antara batuan dasar (basement) dengan batuan sedimen. Perpotongan antara gradient pertama dan kedua adalah bilangan gelombang $k c$ (cutoff) yang memiliki nilai 0,360 (Gambar 9). Nantinya nilai rata-rata kedalamandangkal akan digunakan untuk membuatpemodelan struktur bawah permukaan, dannilai bilangan gelombang $k c$ (cut off) merupakan dasar dalam penentuan lebar jendela pada penapisan moving average. 


\subsection{Filter Moving Average}

Proses filter moving average pada penelitian ini dibantu/proses dengan menggunakan perangkat lunak Geosoft.

Pada proses analisis spektral diketahui lebar jendela optimal yang dapat digunakan adalah 7, maka lebar jendela yang digunakan untuk proses penapisan (filtering) adalah $(18 \times 18) \mathrm{km}$, jika dirubah kedalam satuan UTM,maka nilainya menjadi 18000. Nilai ini akan digunakan sebagai input pada filter moving average dengan menggunakan perangkat lunak Geosoft. Hasil dari penapisan moving averageadalah peta anomali regional dan anomali residual.

\subsection{Anomali Regional}

Anomali regional merupakan anomali dalam, yaitu anomali yang bersumber dari bagian dalam bumi contohnya adalah kerak bumi, anomali ini dicirikan dengan frekuensi rendah. Gradasi warna pada peta menunjukkan variasi nilai anomali yang terdapat pada daerah penelitian. Peta anomali regional menunjukkan rentang nilai anomali sebesar $4 \mathrm{mGal}$ sampai 97 mGal. Anomali rendah ditunjukkan dengan warna biru tua dan biru muda, anomali sedang ditunjukkan dengan warna hijau dan kuning, dan anomali tinggi ditunjukkan dengan warna jingga, merah dan merah muda (Gambar 10).

\subsection{Anomali Residual}

Hasil dari pola anomali Bouguer dan anomali regional belum dapat menggambarkan atau menunjukkan secara detail pola struktur daerah penelitian. Untuk mengetahui pola struktur yang lebih dangkal, maka dilakukan penapisan (filtering) untuk mendapatkan pola anomali residual. Anomali residual didapatkan dari pengurangan anomali Bouguer dengan anomali regional. Anomali residual yang diperoleh mempunyai rentang nilai antara-4 mGal sampai 4 mGal (Gambar 11).
Peta anomali residual menunjukkan pola anomali yang lebih kompleks dibandingkan dengan anomali regional. Pola anomali ini dibagi kedalam tiga lajur anomali yang berbeda. Anomali residual ditunjukkan dengan warna biru tua sampai dengan merah muda dengan rentang nilai antara -4 sampai $4 \mathrm{mGal}$.

\subsection{2,5D Forward Modeling dan Analisis Derivative}

Pada Penelitian kali ini penulis membuat 3 penampang lintasan pada anomali residual, yaitu lintasan A-A', B-B', C-C' untuk mengetahui pola struktur secara umum (Gambar 12).

\subsubsection{Penampang A-A'}

Penampang lintasan A-A' memiliki panjang lintasan 40,65 km. Dari informasi geologi lintasan ini melewati 3 formasi, yaitu Endapan aluvium dan litoral (Qa), Formasi Kemum (SDk), dan Granodiorit Wariki (TRw).

Berdasarkan analisis pemodelan 2D pada lintasan ini tidak ditemukan adanya struktur sesar turun maupun intrusi batuan. Hal tersebut dikarenakan respon grafik observasi yang dihasilkan tidak menggambarkan adanya patahan dan juga intrusi batuanbawah permukaan pada daerah tersebut (Gambar 13).

\subsubsection{Penampang B-B'}

Penampang lintasan B-B' memanjang dengan arah relatif Utara ke Selatan dan melewati sistem sesar Ransiki (Gambar 14). Penampang lintasan B-B' memiliki panjang lintasan $34,38 \mathrm{~km}$. Dari informasi geologi lintasan ini melewati 4 formasi, yaitu Formasi Kemum (SDk), Diorit Lembai (Tmle), Formasi Befoor dan Endapan aluvium dan litoral (Qa). Pada penampang B-B' ini diidentifikasikan terdapat adanya suatu intrusi yang terjadi akibat adanya suatu sesar (Gambar 14). 


\subsubsection{Penampang C-C'}

Penampang lintasan C-C' memiliki panjang lintasan $62 \mathrm{~km}$.Dari informasi geologi lintasan ini melewati 4 formasi, yaitu Formasi Kemum (SDk), Batuan Gunung Api (Tema), Bancuh tak terpisahkan di dalam sistem sesar Ransiki (RFx) dan Endapan aluvium dan litoral (Qa). Model 2,5 D menunjukkan bahwa pada daerah tersebut terdapat sistem sesar naik yang merupakan sistem sesar Ransiki. Analisis tersebut berdasarkan hasil kurva SVD, dimana nilai pada kurva tersebut nilai SVD maksimum lebih kecil dari nilai mutlak SVD maksimum. Pada analisis kurva FHD memperlihatkan batas kontak struktur geologi yang bernilai maksimum (Gambar 15).

Dan penulis melakukan mengkorelasikan antara ketiga pemodelan 2D forward modeling tersebut dan hasilnya sesuai atau berhubungan satu sama lain antar lapisan litologi batuan tersebut (Gambar 16).

\section{Kesimpulan}

Daerah penelitian memiliki nilai anomali Bouguer antara $4 \mathrm{mGal}$ sampai 96 mGal dengan anomali rendah pada bagian kiri daerah penelitian yang memanjang dengan arah relatif baratlaut-tenggara, anomali sedang berada pada bagian tengah daerah penelitian yang tersebar di daerah barat-timur daerah penelitian, anomali tinggi tersebar pada bagian utara daerah penelitian.

Berdasarkan analisis FHD dan SVD 3 lintasan pada daerah penelitian (A-A', B-B', dan C-C') di identifikasi terdapat adanya intrusi batuan dan juga sesar naik. Pada lintasan A-A' berdasarkan pemodelan 2D bawah permukaan tidak ditemukan adanya intrusi batuan jika dilihat dari respon observasi data gravity dan hanya berupa perlapisan batuan. Pada lintasan B-B' dan C-C' yang memotong sesar Ransiki di identifikasikan adanya intrusi batuan pada lintasan B-B' sedangkan pada lintasan C-C' terdapat adanya sistem sesar naik (Thrust
Fault) dengan nilai FHD maksimum dan minimum yang menunjukkan batas bidang kontak dan nilai SVD memperlihatkan nilai SVD minimum lebih besar daripada nilai mutlak SVD maksimum.

Hasil pemodelan bawah permukaan 2,5D menunjukkanm letak patahan pada pemodelan 2,5D sesuai dengan respon grafik SVD yang diperoleh dari peta anomali SVD residual.

Batuan pengisi dari penampang struktur bawah permukaan yang dilewati oleh sesar Sorong yaitu Formasi Kemum (SDk) dengan densitas 2,65 gr/cc, Endapan Aluvium (Qa) dengan densitas 2,3 gr/cc. pada sesar Ransiki batuan yang tersesarkan yaitu Diorit Lembai (Tmle) dengan densitas 2,75 gr/cc dan Bancuh (RFx) yang tersusun oleh Batugamping tergeruskan dengan densitas sebesar 2,67 gr/cc, dan batuan Gunung Api (Tema) dengan nilai densitas $2,55 \mathrm{gr} / \mathrm{cc}$.

\section{Daftar Pustaka}

Blakely, R. J. 1996. Potensial Theory in Gravity and Magnetic Applications. Cambridge: Cambridge University Press.

Cordell, L. 1979. Gravimetric Expression of Graben Faulting in Santa Fe Country and Espanola Basin, New Mexico. New Mexico. Geol. Sot. Guidebook, 30 ${ }^{\text {th }}$ Field Conf., 59-64.

Elkins, T. A. 1951. The Second Derivative Method of Gravity Interpretation.

Geophysics, v.23, h.97-127.

Hartati, A. 2012. Identifikasi Struktur Patahan Berdasarkan Analisa Derivative Metode Gayaberat Di Pulau Sulawesi. (Skripsi) Depok: Universitas Indonesia

Robinson GP, Ratman N, dan Pieters PE. 1990. Geologi Lembar Manokwari, Irian Jaya. Bandung: Pusat Penelitian dan Pengembangan Geologi Departemen Pertambangan dan Energi. 
Setiadi, I., Pratama, A. W. 2018. Pola Struktur dan Konfigurasi bawah permukaan Cekungan Jawa Barat Utara

berdasarkan analisis gayaberat, Jurnal Geologi dan Sumber Daya Mineral, V. 9, No. 2, h. 59-72

Talwani, M., Worzel, J.L. dan Landisman, M. 1969. Rapid Gravity Computations for Two-Dimensional Bodies with Aplication to the Mendocino Submaarine Fracture Zone. Journal of Geophysical Reasearch: Vol.64 No.1

Telford, W.M., Goldrat, L.P., dan Sheriff, R.P. 1990. Applied Geophysics 2nd ed. Cambridge University Pres, Cambridge.

Zaenudin, A., Sarkowi, M., dan Suharno. 2013. Pemodelan Sintetik Gradien Gayaberat Untuk Identfikasi Sesar. Prosiding Seminar Nasional, LPPM UNILA. 
Tabel 1. Operator Elkins filter SVD (Elkins, 1951)

\begin{tabular}{|lllll|}
\hline \multicolumn{5}{|c|}{ Operator Filter SVD menurut Elkins (1951) } \\
\hline 0.0000 & -0.0833 & 0.0000 & -0.0833 & 0.0000 \\
-0.0833 & -0.0667 & -0.0334 & -0.0667 & -0.0833 \\
0.0000 & -0.0334 & +1.0668 & -0.0334 & 0.0000 \\
-0.0833 & -0.0667 & -0.0334 & -0.0667 & -0.0833 \\
0.0 & -0.0833 & 0.0000 & -0.0833 & 0.0000 \\
\hline
\end{tabular}

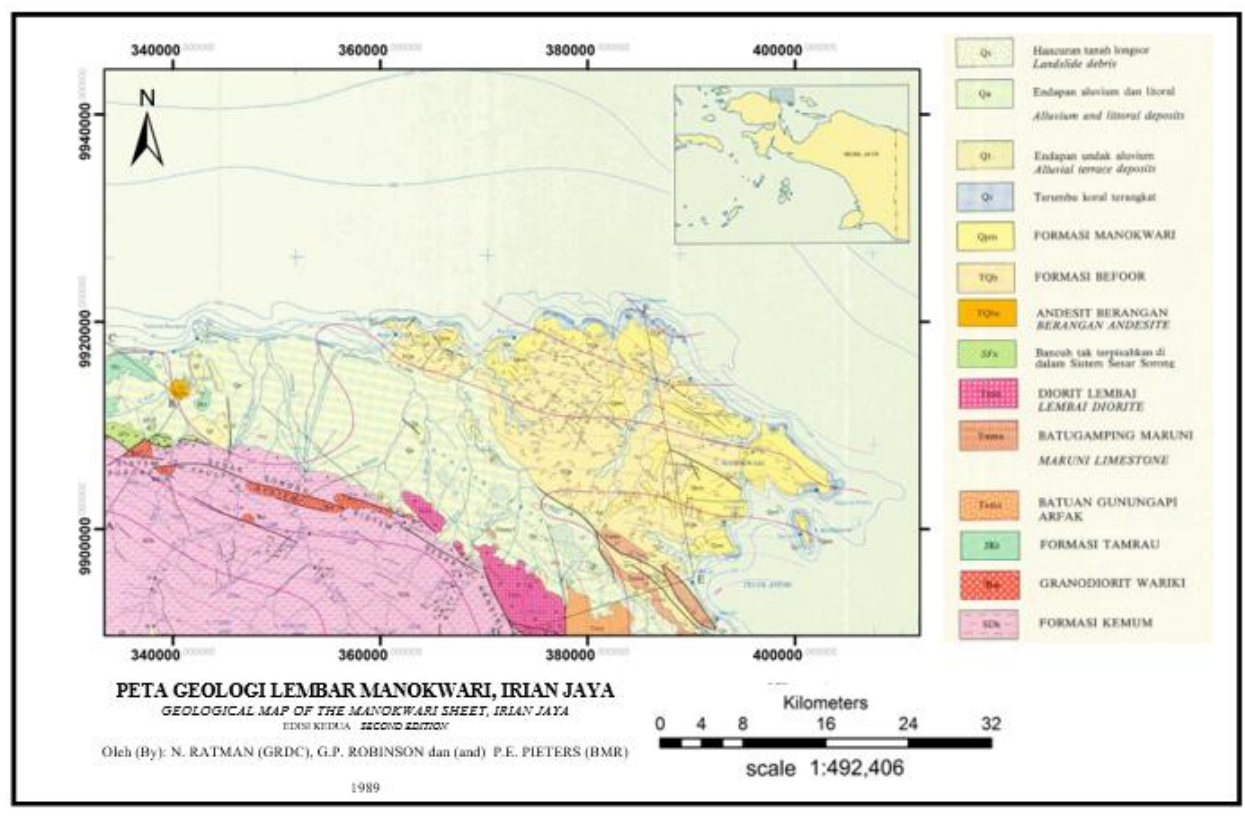

Gambar 1. Peta Geologi Daerah Penelitian

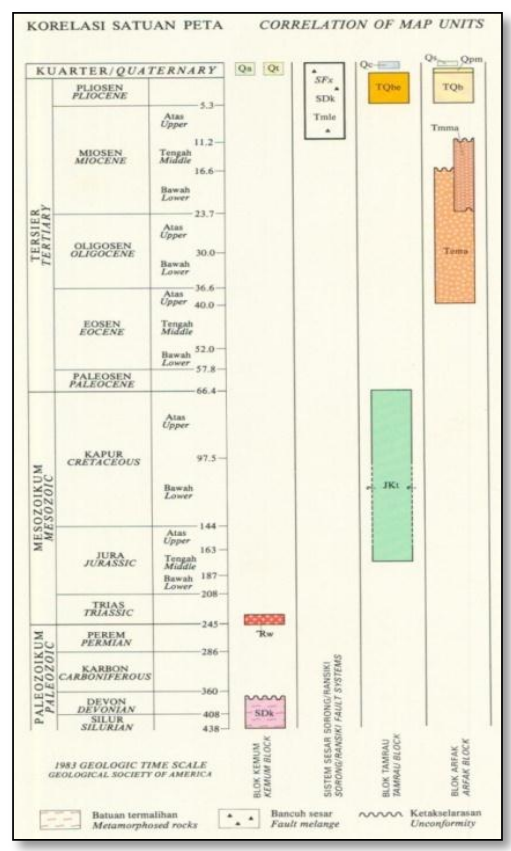

Gambar 2. Stratigrafi Daerah Penelitian (Robinson dkk, 1990). 


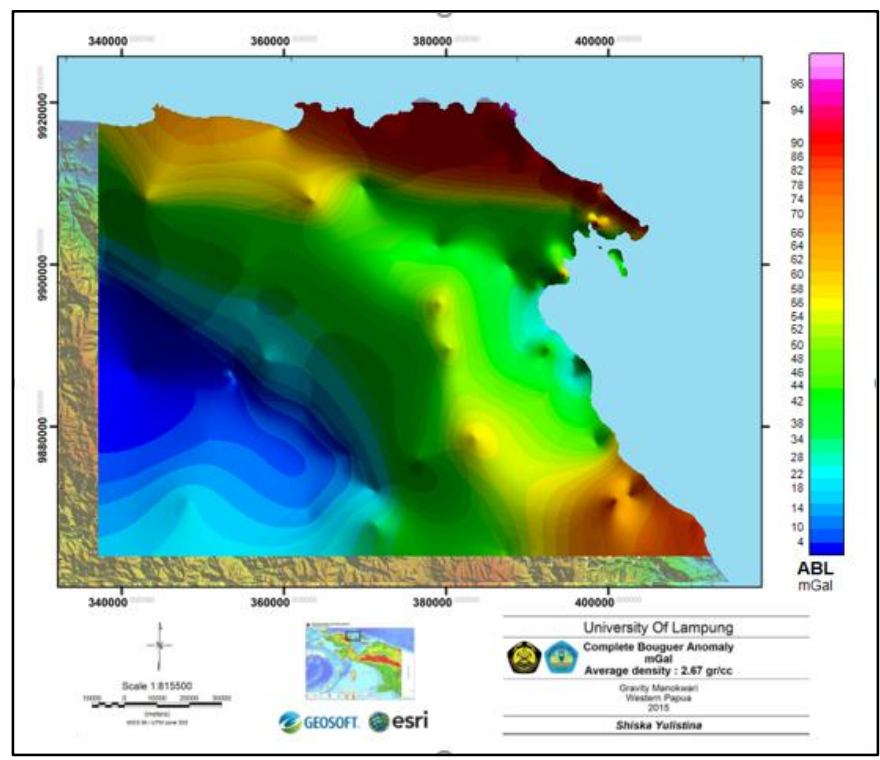

Gambar 3. Peta Anomali Bouguer Lengkap Daerah Penelitian

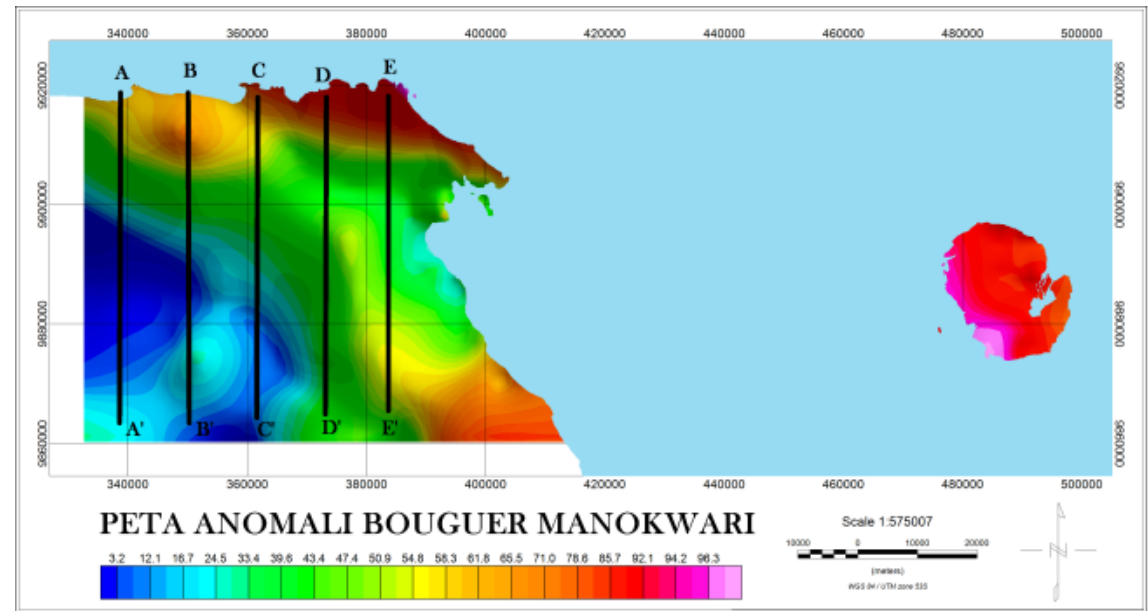

Gambar 4. Lintasan Pada Peta Anomali Bouguer Lengkap 


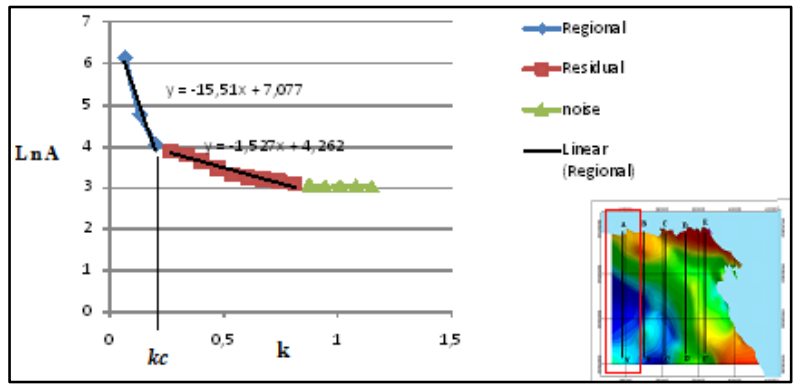

Gambar 5. Grafik Ln A vs k Lintasan A-A'

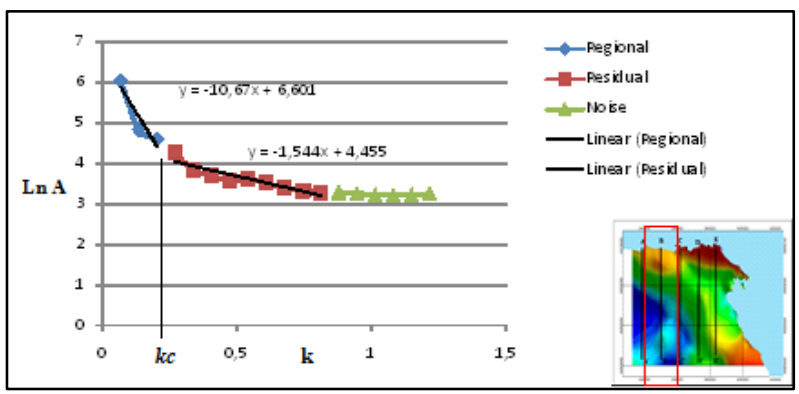

Gambar 6. Grafik Ln A vs k LintasanB-B'

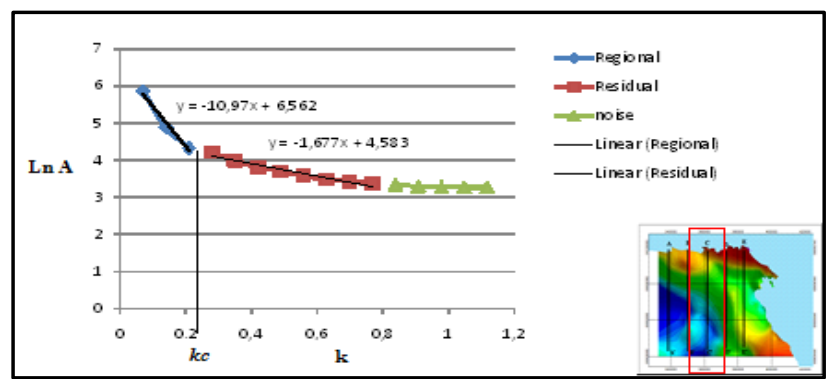

Gambar 7. Grafik Ln A vs k LintasanC-C'

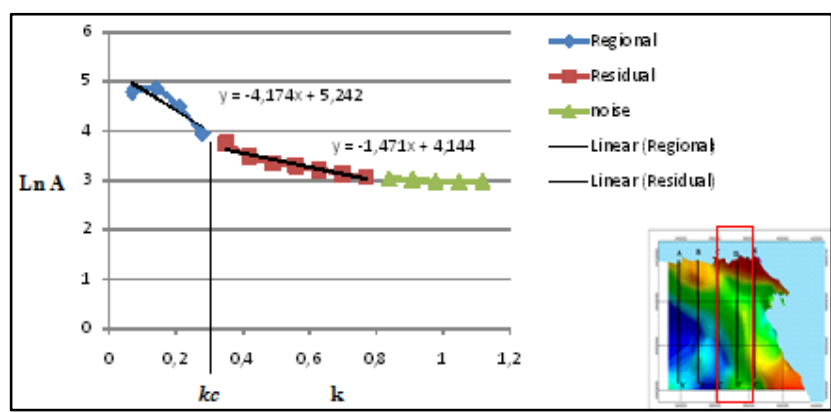

Gambar 8. Grafik Ln A vs k LintasanD-D’

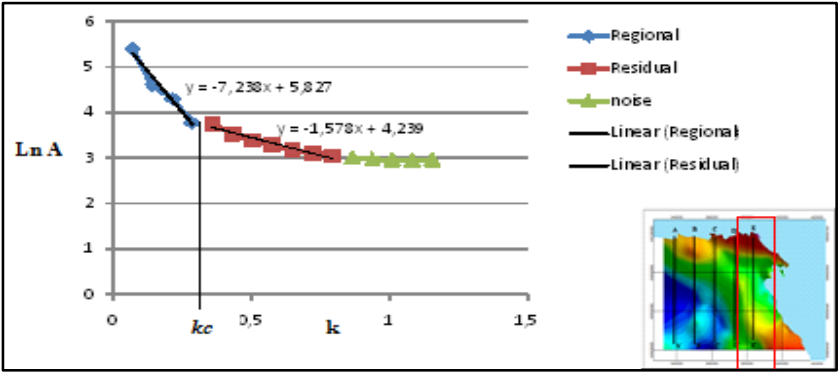

Gambar 9. Grafik Ln A vs k LintasanE-E' 


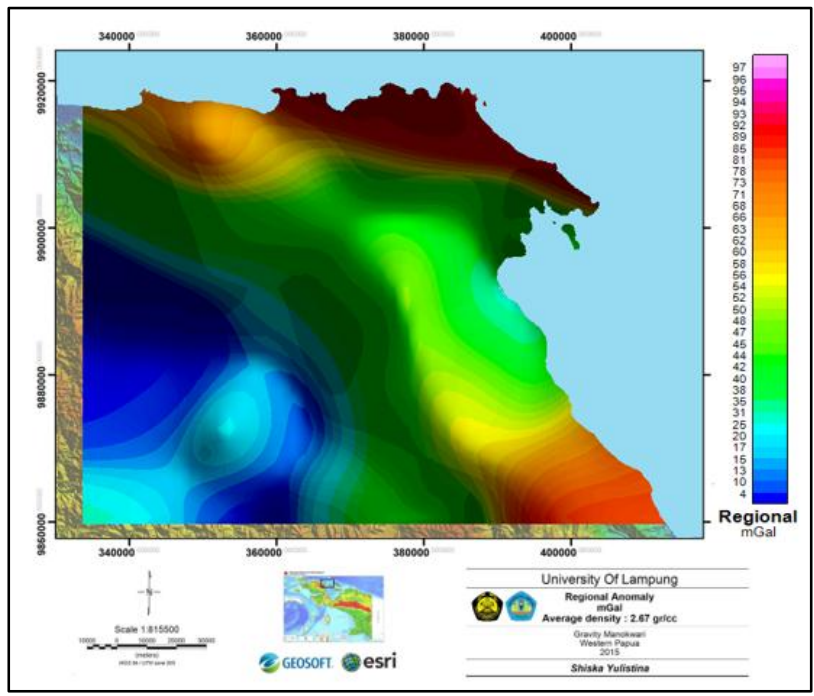

Gambar 10. Peta Anomali Regional Daerah Penelitian

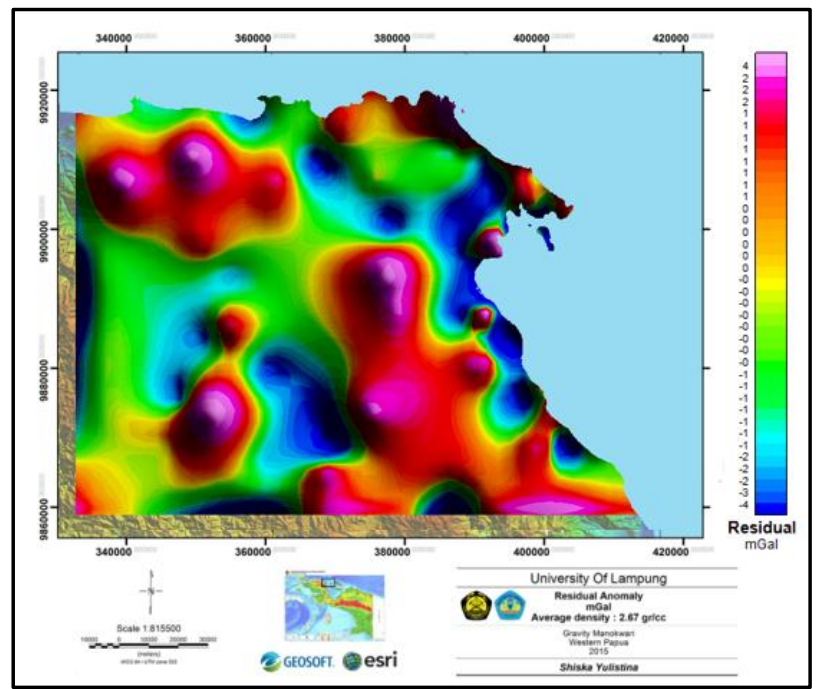

Gambar 11. Peta Anomali Residual Daerah Penelitian

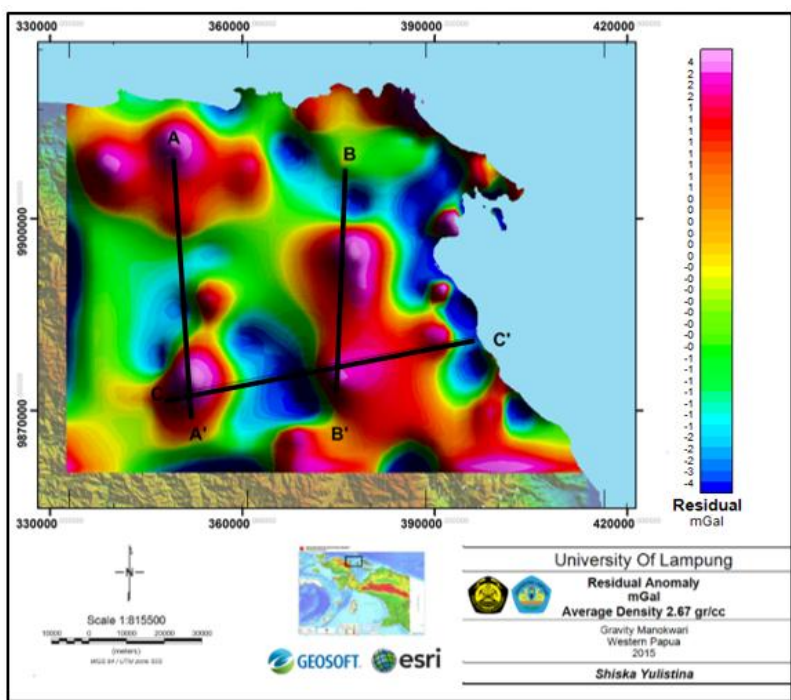

Gambar 12. Peta AnomalResidual denganlicing penampangnalisis $F H D, S V D$, dan $2,5 D$ Forward Modeling 


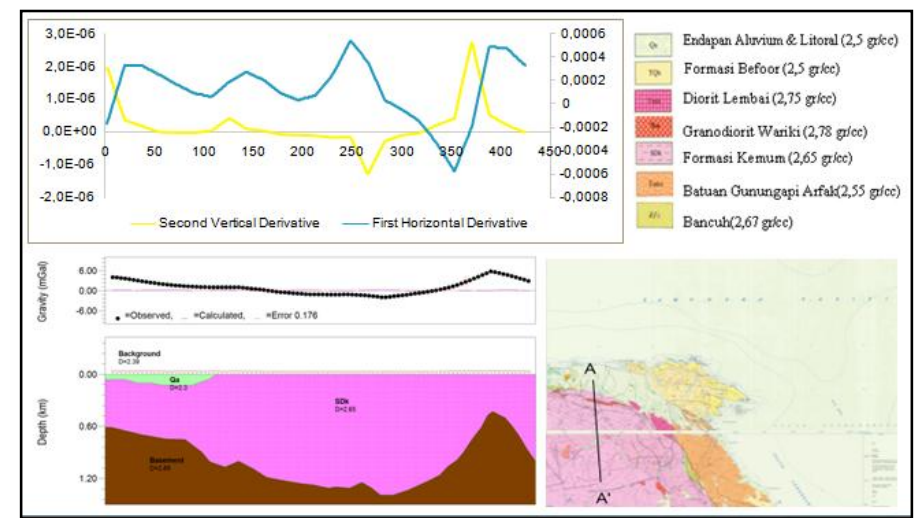

Gambar 13. Model Bawah Permukaan Anomali Residual 2,5D Lintasan A-A'

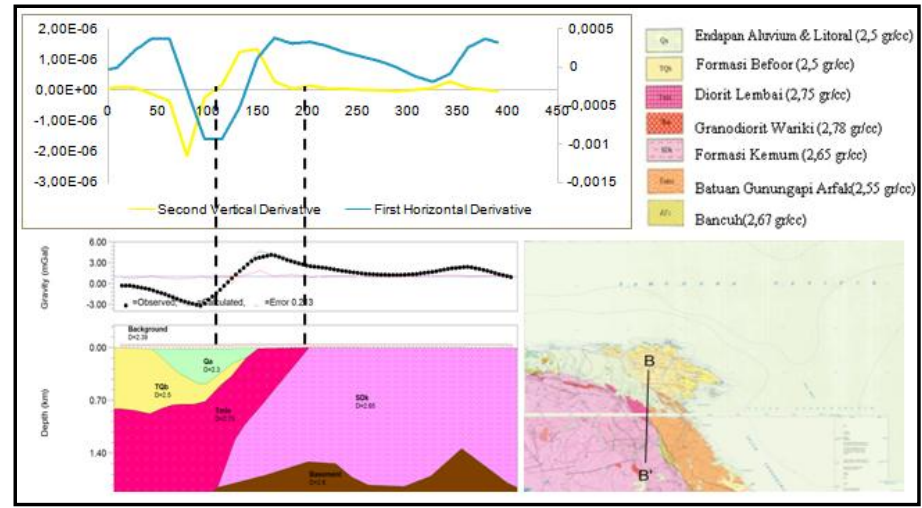

Gambar 14. Model Bawah Permukaan Anomali Residual 2,5D Lintasan B-B'

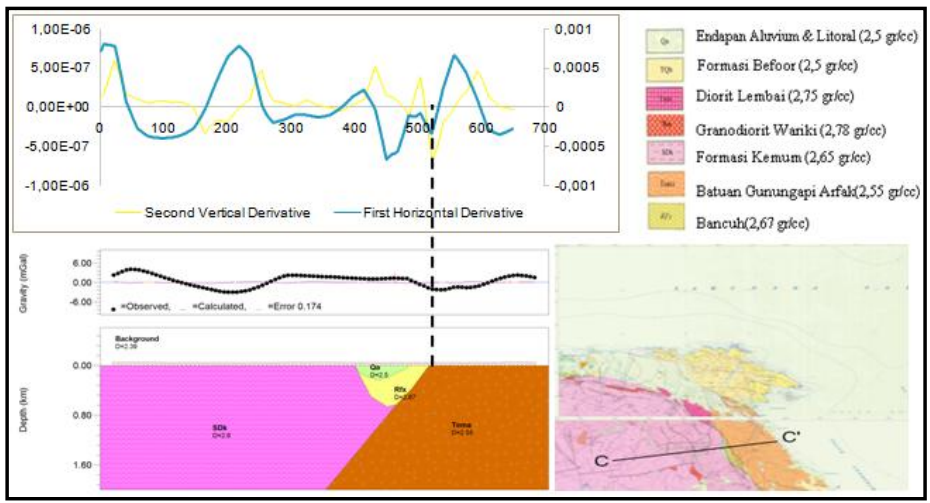

Gambar 15. Model Bawah Permukaan Anomali Residual 2,5D Lintasan C-C'

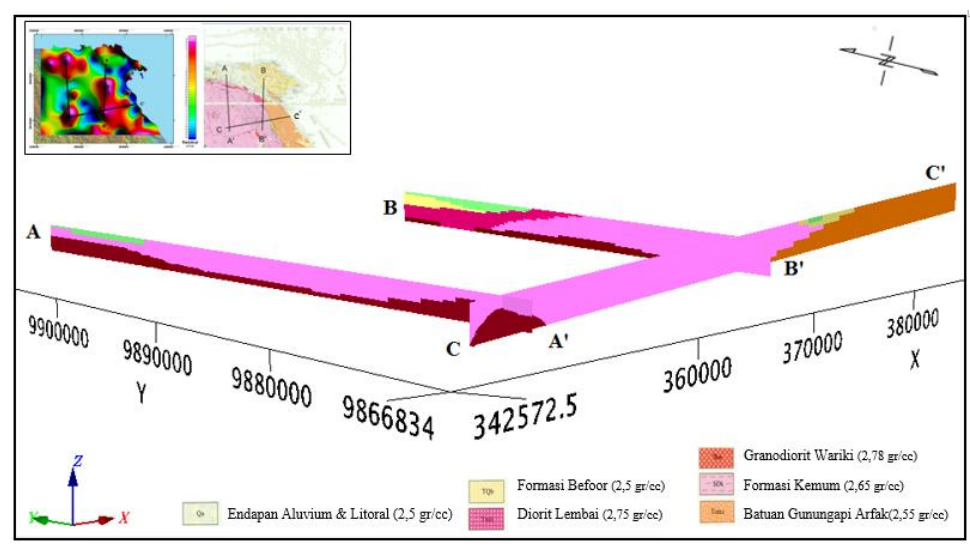

Gambar 16. Korelasi Model 2D Forward Modeling A-A', B-B' dan C-C' 